\title{
Norma dan Eksploitasi Tipe Semantis Properti Fisik Adjektiva Pada Frasa Nomina 'Eye' dalam COCA
}

\author{
Ria Herwandar ${ }^{1}$, Risa Utami Putriya Kesuma ${ }^{2}$ \\ ${ }^{1,2}$ Program Studi Sastra Inggris, Fakultas Sastra, Universitas Al Azhar Indonesia \\ Kompleks Masjid Agung Al Azhar, Jalan Sisingamangaraja, Kebayoran Baru, Jakarta Selatan 12110 \\ Penulis untuk Korespondensi/E-mail: ria_herwandar@uai.ac.id
}

\begin{abstract}
Abstrak - Penelitian ini berjudul "Norma dan Eksploitasi Tipe Semantis Properti Fisik Ajektiva pada Frasa nomina 'Eye' dalam COCA'. Bahasannya mengenai klasifikasi adjekitva terhadap nomina'eye'pada tipe semantis PHYSICAL PROPERTY di 50 frekuensi tertinggi dan 50 frekuensi terendah dari 500 frekuensi frasa nomina 'eye'. Metode yang digunakan berdasarkan teori Creswell dalam Research Design Qualitative, quantitative and Mixed Methods Approaches (2009) Hasil temuan dianalisis melalui teori yang diciptakann Hanks, 'Lexical Analysis Norms and Exploitations' untuk melihat dinamika ekspoitasi frasa nomina 'eye'
\end{abstract}

Kata Kunci: Frasa nomina 'Eye' dalam COCA, Teori Hanks, Teori Creswell,

Abstract - This research entitled "Norma dan Eksploitasi Tipe Semantis Properti Fisik Ajektiva pada Frasa nomina 'Eye' dalam COCA'. The study is on the classification of semantic type for PHYSICAL PROPERTY in adjective of 'eye' as noun. The Method used is basing on Creswell theory in Research Design Qualitative, quantitative and Mixed Methods Approaches (2009). The finding is analysed through Hanks' theory ' Lexical Analysis Norms and exploitations', to see the dynamic exploitation of noun Phrase'eye'.

Keywords: Noun Phrase 'Eye' in COCA, Hanks Theory, Creswell Theory.

Latar Belakang

Setiap bahasa memiliki kosa kata yang sangat banyak, bahkan tidak dapat dihitung. Oleh karena itu, kamus dapat membantu manusia untuk mengenal dan memakai kosa kata yang tidak ia kuasai. Masalahnya, bahasa selalu berkembang dan kamus tidak selalu dapat menjawab keinginan manusia untuk lebih banyak mendapat arti atau makna atau kata yang ingin is sampaikan. Oleh karena itu, untuk memahami perkembangan kosa kata dalam suatu bahasa yang selalu berkembang, kamus maupun buku grammatika sudah tidak cukup memuaskan lagi. Misalnya dalam kamus Oxford advanced Learner's Dictionary hanya dijelaskan ajektiva warna dasar seperti a blueeyed blonde $(2000,522)$,sementara data dari korpus yang ada dalam COCA sudah berkembang dengan ajektiva warna blue-black eye, light-blue eye,. Oleh karena itu, Ilmu linguistik terapan yang saat ini sangat menarik untuk diteliti adalah Linguistik korpus.
Linguistik korpus adalah wilayah keilmuan bahasa yang berfokus pada prosedur atau metode dalam menganalisis dan mengeksplorasi bahasa. Corpus linguistics is ' $a$ study of language based on examples of "real life" language use' and 'a methodology rather than an aspect of language requiring explanation or description'. (McEnery and Wilson 1996: 1) Artinya, Korpus linguistik memiliki cara pandang yang sangat luas terhadap pendekatan pengkajian bahasa dan memfasilitasi terciptanya eksploitasi teori teori baru suatu bahasa, di mana teori teori tersebut diinspirasi dari hasil penelitian bahasa yang dipakai yang terdapat dalam bentuk data korpus.

Data korpus adalah kumpulan bahan bahasa atau disebut 'bank' data yang berasal dari penggunaan bahasa dari berbagai sumber misalnya dilihat dari genre, variasi bahasa, dan 
dalam bentuk lisan dan tulisan. A corpus is a collection of pieces of language text in electronic form, selected according to external criteria to represent, as far as possible, a language or language variety as a source of data for linguistic research. (Sinclair 2005: 16).

Keuntungan yang diperoleh ketika memanfaatkan data korpus adalah data yang tersedia sangat luas,dan tidak dapat disaingi dengan hasil pemerolehan data yang dilakukan sendiri secara manual, dan sangat akurat. Kendala seorang peneliti dalam mengumpulkan data secara mandiri adalah bagaimana Ia harus meluangkan waktu, uang dan tenaga yang besar untuk mengumpulkan data. Disamping itu, apakah data yang dicari secara manual sudah memenuhi persyaratan sebagai data yang layak untuk di analisis.

Pada tahun 2008 Corpus of Contemporary American English (COCA) mempublikasikan korpus percakapan dalam jumlah yang sangat besar 78.8 juta kata yang dikumpulkan sejak Desember 2008 dan terus diperluas sejak saat itu. Namun dalam publikasinya ditulis COCA 2008-2015.Perbedaan transkrip percakapan COCA dengan $L L C$ adalah bahwa COCA mengkompilasi transkrip percakapan dari radio dan program telivisi. Jadi, bukan merupakan percakapan pribadi seperti yang ada di $L L C$. Dengan demikian, COCA menyediakan percakapan yang lebih luas yang berasal dari forum publik. Pada saat korpora percakapan dan tulisan dirancang terpisah, COCA yang diciptakan oleh Mark Davies di Brigham Young University, menyajikan keduanya, baik korpora percakapan dan korpora tulisan yang datanya bersumber dari program telivisi di Amerika, radio, buku, majalah, koran dan jurnal. Seluruh sumber ini dibagi dalam lima register dengan ukuran jumlah yang sama besar: (1) percakapan (skript percakapan dari telivisi dan radio), (2) fiksi, (3) majalah populer, (4) koran (dari beragam jenis) dan (5) jurnal akademik dari berbagai keilmuan. COCA merupakan alat yang menawarkan beragam kajian atau penelitian yang tidak terbatas dan menantang bagi para peneliti, mudah dioperasionalkan dan bebas biaya (Hans, 2009:17). Dengan menggunakan data COCA, perkembangan kosa kata dapat dilihat berdasarkan frekuensi tampilan kosakata yang dirujuk.

\section{Pembatasan Masalah}

Peneliti hanya membatasi analisis mengenai tipe semantis ajektiva untuk jenis PROPERTI FISIK yang terdapat dalam frasa nomina atau adjacent collocation di adjektiva+eye yang merupakan sebagian kecil dari penelitian disertasi yang sedang dilakasanakan dalam melengkapi studi S3.

\section{Rumusan Masalah}

1 Apa yang dimaksud dengan frasa nomina dan 'Adjacent Collocation' apa sajakah yang berpadanan dengan nomina' eye'?

2 Bagaimana bentuk tipe semantis ajektiva frasa nomina 'eye'?

3 Tipe semantis ajektiva PHYSICAL PROPERTY (PROPERTI FISIK) apa saja yang muncul dengan nomina'eye'?

4 Norma dan eksploitasi apa saja yang muncul dari tipe semantik Properti fisik nomina 'eye'

\section{Tujuan Penelitian}

Tujuan umum dari penelitian ini adalah melihat kontribusi hasil analisis bahasa dengan menggunakan data dalam COCA di ranah linguistik korpus sehingga dapat memahami bagaimana suatu bahasa berkembang.

1. Menjelaskan apa yang dimaksud dengan frasa nomina dan 'adjacent collocation' terhadap nomina 'eye'

2. Mendeskripsikan bentuk 'Semantic type' atau tipe semantik ajektiva frasa nomina'eye'

3. Menganalisis tipe semantis ajektiva PHYSICAL PROPERTY (PROPERTI FISIK) nomina 'eye'

4. Menganalisis temuan norma dan eksploitasi tipe semantik ajektiva Property Fisik nomina 'eye'

\section{Manfaat Penelitian}

Penelitian ini dapat menyumbangkan wawasan bagaimana seseorang belajar atau mengajar bahasa dengan cara yang berbeda dari cara yang konvensional. Dahulu seseorang belajar bahasa hanya menggunakan buku ajar, buku grammatika dan kamus saja. Sekarang, bahasa dapat diamati dan dipembelajari dengan menggunakan atau memanfaatkan data korpus. Data korpus dapat memberikan penjelasan yang lebih luas sehingga merupakan pembelajaran yang lebih eklektik atau menyeluruh karena data korpus dapat memberikan jangkauan yang lebih jauh dan banyak dari sarana yang 
terdahulu. Contohnya sebagai berikut: norma dalam bahasa adalah suatu ungkapan yang sudah berterima dan ditandai dengan kebermunculannya atau frekuensinya sangat tinggi dalam COCA. Kebermunculan tertinggi dari ajektiva+'eye' dalam tipe semantik warna adalah 'blue eye' dengan frekuensi sebanyak 3673 dari total 31984. Hal ini terungkap dalam data korpus yang memberikan data penutur jati sehingga lebih otentik dan alamiah.

Norma dari frasa nomina ini diperkuat oleh kamus OALD (Oxford Advanced Learner dictionary edisi 2000) yang salah satu definisinya adalah 'part of the body' blue eyes'. Kamus hanya menjelaskan warna dasar saja,sehingga ketika terlihat dalam COCA kepadanan yang langka dari frasa nomina lain seperti ' blue-black eye', maka hal ini harus dianalisis kebermaknaannya dalam teks yang ada di COCA. Kepadanan yang berbeda inilah yang akan dan dapat memperkaya makna yang tidak ada dalam kamus yang menjadi manfaat bagi para pengamat dan pelajar bahasa.

\section{KAJIAN TEORI}

\section{Penelitian Terdahulu}

Penelitian terdahulu mengenai frasa nomina berkaitan dengan anggota tubuh seperti 'eye, nose, hand' dan sebagainya, dilakukan oleh Levin dan Lindquist (2007). Mereka membahasa 'nose' dalam artikel berjudul Sticking one;s nose in the data: evaluation in fhraseological sequences with nose, yang diterbitknan dalam ICAME Journal Volume 31: May 2007. Masalah yang dibahas adalah fungsi evaluative dari rangkaian frasa nomina 'nose' kemudian dibahas fungsi metonimi dan metafora yang ada di dalamnya. Pilihan momina nose merujuk pada pendapat dalam linguistik kognitif dimana manusia akan menggunakan pengalaman sebagai kognitifnya sehingga rangkaian fraseologis mengenai nomina berkaitan dengan anggota tubuh banyak terdapat dalam data korpus. Penelitian ini merujuk pada penelitian terdahulu dalam evaluasi dan pendekatan semantic prosody (sinclair 1991), yang membahas makna konotasi dalam gabungan kata. Contoh semantic prosody misalnay frasa verba set in biasanya mengidentifikasi sesuatu yang tidak diinginkan atau negative seperti disillusionment dan ini diasosiasikan dengan suatu kejadian yang tidak menyenamgkan.

\section{Satuan Leksikal}

'Kata' dapat dijelaskan melalui kalimat berikut ini: The headword list is a list of words that are the headwords of entries in the dictionary. Jumlah keseluruhan kata dalam kalimat ini adalah 18. Apabila the dan list tidak dihitung secara kata terpisah maka jumlahnya menjadi 14, dan jika headword dan headwords dikelompokkan pada makna yang sama walau memiliki dua bentuk yang berbeda sehingga jumlahnya menjadi 13. Dapat dikatakan kalimat tersebut memiliki 18 token, 14 jenis/types dan 13 leksem/ lemmas (Atkins, 2008:162). Leksem adalah satuan leksikal dasar yang abstrak yang mendasari pelbagai bentuk infleksi suatu kata; misalnya dalam bahasa Inggris sleep, slept, sleeps, sleeping adalah bentuk bentuk dari leksem sleep (Kridalaksana, 1982:141).

Satu kata leksem memiliki satu atau beberapa arti. Cruse (1991:24) memberikan batasan mengenai satuan leksikal sebagai berikut: 1) $a$ lexical unit must be at least one semantic constituent, 2) a lexical unit must be at least one word. Satuan leksikal bisa terdiri atas beberapa kata seperti dalam frasa verba seperti set off yang memiliki berbagai arti termasuk (1) begin a journey, (2) detonate a bomb (Atkin, 2008:162) dan di kamus disebut sebagai headword atau kata utama yang memiliki makna kamus atau a dictionary sense.

\section{Jenis Satuan Leksikal}

Satuan leksikal mencakup segala kata, singkatan atau abbreviation, bagian kata atau partial word dan frasa yang tampil di kamus, sebagai kepala kataatau kata utama pada kamus, yang menjadi target suatu bentuk deskripsi leksikografi (Atkins dan Rundell, 2008: 163). Dari ke 4 jenis itu dapat dibagi dua menjadi kelompok Single items dan kelompok multiword expressions.

\section{Simple words (kata sederhana)}

Kelompok single item termasuk kata sederhana atau simple words, seperti misalnya be, like, head, possible, remember. Jenis kata sederhana meliputi semua kelas kata baik berkatagori kata leksikal atau kata gramatikal. 
Kata leksikal (lexicalwords) terdiri atas nomina, adjektiva, verba, adverbia dan interjeksi atau kata seru. Kelompok ini disebut opened-category items dan kata kata ini sering memiliki berbagai makna atau arti, menjadi jumlah yang sangat besar di suatu bahasa dan mendominasi definisi dan arti dalam kamus.

Kata gramatikal (grammatical words) disebut sebagai function words atau closed-category items. Menurut Atkins dan Rundell (2008), kata gramatikal mencerminkan fungsi dalam kalimat dan paling sedikit ada lima jenis kata gramatikal yakni:

1. Preposisi seperti to, from, with, up

2. Konjungsi seperti because, when, and, so;

3. Pronomina seperti we, yourself, his, that, which, what, none, some, all;

4. Auxiliary verb seperti be, do, have dan modalitas, may, could dan lainnya;

5. Determiners termasuk definite dan indefinite ariticles, demonstratives, possesive, numerals, negatives, quantifiers dan predeterminers seperti the, a, this, his, three, no, some, all.

\section{Abbreviation (Singkatan)}

Jenis single item lkelompok ini dibagi menjadi tiga kelompok kecil yang hampir di setiap kamus mendapat status headword seperti:

a) Alfabetisme adalah huruf awal kelompok kata kata , dengan pengucapan huruf seperti $B B C$

b) Akronim adalah huruf awal kelompok kata kata, dengan pengucapan kata seperti NATO

c) kontrasksi adalah dua kata atau lebih dengan beberapa huruf yang di buang seperti don't, would'nt.

\section{Partial Words (Bagian Kata)}

Partial Words termasuk dalam single items dengan rincian sebagai berikut:

a) Bound affixes (afiks terikat) seperti misalnya: im-(impossible), -ment (attainment).

b) Productive affixes seperti pefiks exmenempel pada nomina seperti ex-wife yang menandakan status pada orang. Suffiks -gate dalam Monica-gate menandakan suatu kasus perselingkuhan Clinton-Lewinsky. Contoh lain Zippergate di dunia media pemberitaan c) Combining forms adalah bentuk headword atau bentuk infleksi yang muncul sebagai elemen pertama atau kedua dari gabungan kata yang diberi garis penghubung. Makna masing masing kata bergaris penghubung tetap konstant tetapi proses penggabungan dapat berubah atau disebut open-ended. Contohnya menurut Atkins (2008) ada dalam bilangan atau numerals seperti one-legged, nomina seperti vinyl-covered, dan adjektiva seperti flatleafed.

\section{Multiword Expressions (ekspresi beberapa kata) \\ Multiword expressions (MWE) sulit untuk diuraikan dan diidentifikasi. Banyak kamus mengulas tentang frasa dan gabungan verba tetapi karena banyak subkelas dalam kriteria MWE menyebabkan batasan satu sama lainnya melebur sehingga tidak secara utuh dijelaskan.}

Pada setiap Bahasa, MWE merupakan inti dari kekayaan kosakata. MWE penting dijelaskan karena pengguna bahasa ke dua sering tidak paham atau mengerti signifikansi makna MWE walau sebagian MEW mudah untuk dimengerti (seperti kith and kin, kick the bucket, birds of feather), namun banyak MWE tidak memiliki makna idiomatic yang mutlak seperti contoh diatas. Salah satu kriteria makna dari MWE adalah its meaning is more than the sum of its parts. Salah satu jenis MWE (Atkins dan Rundell, 2008:167-172) MWE adalah compound.

Compounds dalam MWE, ada yang merupakan gabungan kata yang idiomatis dan non idiomatis dan sangat sulit membedakan juga dalam maknanya ketika menganalisi korpus. Contoh gabungan kata dengan makna figuratif a lame duck bukan berarti bebeknya yang pincang, atau civil servant bukan berarti pembantu yang negeri atau sopan, bahkan artinya jauh dari makna tersebut. Gabungan kata dengan makna semi figuratif contohnya high school bukan bermakna gedung sekolah yang tinggi. Contoh lain disebut gabungan kata fungsional mencerminkan benda atau persona yang khusus seperti house agent (bukan berarti semua yang menjual rumah menjadi agen porperti), police dog (anjing polisi bukan jenis anjing spaniel atau poodle). 


\section{Makna Leksikal}

Kata hanya menonjolkan makna potensial apabila tidak memiliki suatu konteks (Hanks, 2013:73). Makna satuan leksikal dapat dikelompokkan dalam pola frasa sehingga makna dapat meluas dari makna litera menjadi nonliteral dan metafora (Cruse, 1999:239).

\section{Tipe Semantis Adjektiva}

Dalam menganalisis frasa nomina eye digunakan tipe semantis adjektiva yang diklasifikasikan oleh Dixon menjadi 11 (sebelas) kategori (1990) dan berkembang menjadi 13 (tiga belas) (2004) kategori yakni:

1. DIMENSION-merujuk pada ukuran seperti, big, round, great, narrow, deep.

2. PHYSICAL PROPERTY-merujuk pada indera, konfigurasi, tekstur seperti, hard, sweet, cool, noisy, juga sub tipe CORPOREAL, well, sick, ill, dead.

3. SPEED-merujuk pada kecepatan seperti fast dan slow

4. AGE-usia seperti old, young, modern

5. COLOUR- merujuk pada warna seperti red', 'blue'

6. VALUE-merujuk pada nilai seperti 'good', 'bad', 'perfect'

7. DIFFICULTY - merujuk pada tingkat kesulitan seperti 'easy', 'difficult'

8. VOLITION-merujuk pada kemauan diri seperti 'deleberate', 'accidental', 'purposeful'

9. QUALIFICATION-kualifikasi dengan beberapa subtipe seperti 'definite', 'possible', 'usual',

10. HUMAN PROPENSITY-kecirian manusia seperti kondisi mental, kondisi fisik, perilaku

1. antara lain 'jealous', 'ashamed', 'weak', 'thirsty', 'wild', 'funny'

11. SIMILARITY merujuk membandingkan dua hal seperti 'like' dan 'unlike'

12. POSITION- merujuk pada posisi seperti 'left' dan 'right'

13. CARDINAL NUMBER- merujuk pada angka seperti pertama first, second

\section{Teori Norma dan Eksploitasi (TNE)}

Menurut Hanks (2013) norma adalah pola umum dalam pemakaian bahasa sehari hari dan tercermin dalam kamus karena merupakan first order element of pattern, of normal uses in normal pattern pemakaian dengan frekuensi tertinggi. Eksploitasi adalah penggunaan bahasa yang dinamis, emotif, kreatif dari batasan yang ada sebagai ungkapan baru dari pola yang lama.

\section{METODE PENELITIAN}

\section{Pendekatan Mixed Method}

Penelitian ini merupakan bagian kecil dari penelitian yang lebih besa yaitu bagian dari disertasi yang sedang di proses dengan Judul Norma dan Eksploitasi kata 'Eye' dalam COCA. Metode yang digunakan adalah metode gabungan Mixed methods antara kualitatif dan kuantitatif. Teori ini dirancang oleh Creswell dalam bukunya berjudul Research Design Qualitative, quantitative and Mixed Methods Approaches (2009) Mengapa karena dalam linguistik korpus peneliti harus memilah dan menghitung ulang jumlah frekuensi kebermuculan kosa kata yang ada dalam COCA. Setelah itu data data di analisis kembali secara kualitatif.

\section{Data dan Sumber Data}

Partisipan Penelitian adalah nomina 'eye' dan adjectiva yang mendampinginya dalam jumlah frekuensi 50 tertinggi dan terendah dari 500 frekuensi kolokasi bersebelahan nomina eyes dalam COCA (Corpus of Contemporary American English). Dari kepala kata atau headword eye, juga kalimat dari berbagai jenis teks seperti teks berita, majalah, koran dan percakapan dilibatkan sebagai partisipan penelitian untuk dianalisis.

Tabel 1. Data 50 frekuensi tertinggi dan 50 frekuensi terendah dari 500 frekuensi kolokasi bersebelahan adjektiva+'eyes' dengan indikasi nomer 1-50 dan nomer 450 dampai 500 frekuensi.

\begin{tabular}{|l|l|l|l|l|}
\hline & $\Gamma$ & CONTEXT & FREQ \\
\hline 1 & $\Gamma$ & BLUE & 4404 & \\
\hline 2 & $\Gamma$ & BROWN & 2107 & \\
\hline 3 & $\Gamma$ & DARK & 1737 & \\
\hline 4 & $\Gamma$ & BLACK & 1654 & \\
\hline 5 & $\Gamma$ & GREEN & 1468 & \\
\hline 6 & $\Gamma$ & LEFT & 958 & \\
\hline 7 & $\Gamma$ & NAKED & 832 & \\
\hline
\end{tabular}




\begin{tabular}{|c|c|c|c|c|}
\hline 8 & $\Gamma$ & RIGHT & 784 & $\square$ \\
\hline 9 & $\Gamma$ & GRAY & 702 & 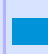 \\
\hline 10 & $\Gamma$ & BLIND & 669 & D \\
\hline 11 & $\Gamma$ & WATCHFUL & 603 & $\square$ \\
\hline 12 & Г & RED & 534 & $\square$ \\
\hline 13 & Г & HUMAN & 510 & $\square$ \\
\hline 14 & Г & HAZEL & 423 & $\square$ \\
\hline 15 & Г & GOOD & 403 & $\square$ \\
\hline 16 & Г & CLOSE & 400 & $\square$ \\
\hline 17 & $\Gamma$ & PRIVATE & 389 & 口 \\
\hline 18 & Г & BIG & 330 & $\square$ \\
\hline 19 & $\Gamma$ & YELLOW & 312 & $\square$ \\
\hline 20 & $\Gamma$ & BRIGHT & 299 & $\square$ \\
\hline 21 & $\Gamma$ & SHARP & 291 & $\square$ \\
\hline 22 & $\Gamma$ & WIDE & 283 & 口 \\
\hline 23 & Г & EVIL & 277 & 口 \\
\hline 24 & $\Gamma$ & VERY & 261 & ] \\
\hline 25 & $\Gamma$ & BLOODSHOT & 233 & 口 \\
\hline 26 & $\Gamma$ & KEEN & 233 & 口 \\
\hline 27 & $\Gamma$ & CRITICAL & 225 & 口 \\
\hline 28 & $\Gamma$ & LITTLE & 195 & 】 \\
\hline 29 & $\Gamma$ & OTHER & 195 & 】 \\
\hline 30 & $\Gamma$ & CLOSED & 193 & 】 \\
\hline 31 & Г & $\mathrm{SAD}$ & 192 & 】 \\
\hline 32 & $\Gamma$ & DRY & 189 & $\square$ \\
\hline 33 & Г & LARGE & 189 & $\square$ \\
\hline 34 & $\Gamma$ & BEAUTIFUL & 186 & 】 \\
\hline 35 & Г & PALE & 177 & 】 \\
\hline 36 & Г & GOLDEN & 176 & 【 \\
\hline
\end{tabular}

\begin{tabular}{|c|c|c|c|c|}
\hline 37 & Г & NEW & 166 & I \\
\hline 38 & Г & BEADY & 166 & I \\
\hline 39 & Г & UNTRAINED & 160 & I \\
\hline 40 & Г & UNAIDED & 151 & I \\
\hline 41 & Г & WATERY & 150 & I \\
\hline 42 & Г & OPEN & 147 & I \\
\hline 43 & Г & ROUND & 147 & I \\
\hline 44 & Г & FRESH & 147 & I \\
\hline 45 & Г & WARY & 144 & I \\
\hline 46 & Г & DEEP-SET & 134 & I \\
\hline 47 & Г & COLD & 133 & I \\
\hline 48 & Г & TIRED & 125 & I \\
\hline 49 & Г & CLEAR & 124 & I \\
\hline 50 & Г & EMPTY & 122 & I \\
\hline 451 & Г & RUNNY & 9 & $\square$ \\
\hline 452 & Г & WRONG & 9 & $\square$ \\
\hline 453 & Г & UNREADABLE & 9 & $\square$ \\
\hline 454 & Г & VELVETY & 9 & $\square$ \\
\hline 455 & Г & WEIRD & 9 & $\mathbf{a}$ \\
\hline 456 & Г & WHOLE & 9 & $\square$ \\
\hline 457 & Г & HONEY-COLORED & 9 & $\square$ \\
\hline 458 & Г & HALF-LIDDED & 9 & $\square$ \\
\hline 459 & Г & HALF-OPEN & 9 & $\square$ \\
\hline 460 & Г & FALSE & 9 & $\square$ \\
\hline 461 & Г & FACETED & 9 & $\square$ \\
\hline 462 & Г & FLICKERING & 9 & $\square$ \\
\hline 463 & Г & FULL & 9 & $\square$ \\
\hline 464 & Г & FROZEN & 9 & $\square$ \\
\hline 465 & $\Gamma$ & FOREIGN & 9 & $\square$ \\
\hline
\end{tabular}




\begin{tabular}{|c|c|c|c|c|}
\hline 466 & $\Gamma$ & GLOSSY & 9 & $\square$ \\
\hline 467 & $\Gamma$ & MYSTERIOUS & 9 & $\square$ \\
\hline 468 & $\Gamma$ & MAD & 9 & $\square$ \\
\hline 469 & $\Gamma$ & INVISIBLE & 9 & $\square$ \\
\hline 470 & $\Gamma$ & INDIAN & 9 & $\square$ \\
\hline 471 & 厂 & CENTRAL & 9 & $\square$ \\
\hline 472 & $\Gamma$ & CAUTIOUS & 9 & $\square$ \\
\hline 473 & Г & BEMUSED & 9 & $\square$ \\
\hline 474 & Г & ALLURING & 9 & $\square$ \\
\hline 475 & Г & EXCELLENT & 9 & $\square$ \\
\hline 476 & $\Gamma$ & EMERALD-GREEN & 9 & $\square$ \\
\hline 477 & $\Gamma$ & DIABETIC & 9 & $\square$ \\
\hline 478 & Г & DELICATE & 9 & $\square$ \\
\hline 479 & $\Gamma$ & DARK-BLUE & 9 & $\mathbf{a}$ \\
\hline 480 & Г & COMPREHENSIVE & 9 & $\square$ \\
\hline 481 & Г & CORRECTIVE & 8 & $\square$ \\
\hline 482 & $\Gamma$ & DAMNED & 8 & $\square$ \\
\hline 483 & Г & DEEP-BLUE & 8 & $\square$ \\
\hline 484 & $\Gamma$ & DESPAIRING & 8 & $\square$ \\
\hline 485 & Г & DISTANT & 8 & $\square$ \\
\hline 486 & $\Gamma$ & DRAMATIC & 8 & $\square$ \\
\hline 487 & Г & DUBIOUS & 8 & $\square$ \\
\hline 488 & Г & ACTUAL & 8 & $\square$ \\
\hline 489 & $\Gamma$ & ACHING & 8 & $\square$ \\
\hline 490 & 厂 & CHINA-BLUE & 8 & $\square$ \\
\hline 491 & Г & BROKEN & 8 & $\square$ \\
\hline 492 & $\Gamma$ & BLUE-BLACK & 8 & $\square$ \\
\hline 493 & Г & BLURRY & 8 & $\square$ \\
\hline 494 & Г & INDIGO & 8 & 口 \\
\hline
\end{tabular}

\begin{tabular}{|c|c|c|c|c|}
\hline 495 & $\Gamma$ & INQUIRING & 8 & $\square$ \\
\hline 496 & Г & ITALIAN & 8 & $\square$ \\
\hline 497 & Г & JADE-GREEN & 8 & $\square$ \\
\hline 498 & Г & LIGHT-BLUE & 8 & $\square$ \\
\hline 499 & Г & LIGHT-BROWN & 8 & $\square$ \\
\hline \multirow[t]{2}{*}{500} & $\Gamma$ & KOHL-RIMMED & 8 & $\square$ \\
\hline & & TOTAL & 37145 & \\
\hline
\end{tabular}

\section{Metode dan Analisis Data}

Langkah langkah yang dikerjakan adalah :

1. Mencari frekuensi adjacent collocation 50 tertinggi dari 500 frekuensi nomina'eye' atau dari adjacent collocation dalam COCA.

2. Mencari frekuensi adjacent collocation 50 terendah dari500 frekuensi nomina'eye'

3. Mencari klasifikasi tipe semantis ajektiva dan memfokuskan pada tipe semantis adjektiva PHYSICAL PROPERTY ketika berkolokasi dengan nomina eyes

4. Data tipe semantis ajektiva Proprti Fisik diseleksi dari frekuensi 50 tertinggi dan frekuensi 50 terendah dari 500 frekuensi.

5. Data klasifikasi dianalisis bedasarkan token yang diambil melalui Key Word In Context atau KWIC, untuk frekuensi 50 tertinggi diambil 30 kalimat dan dari frekuensi 50 terendah diambil seluruh data kalimat yang muncul.

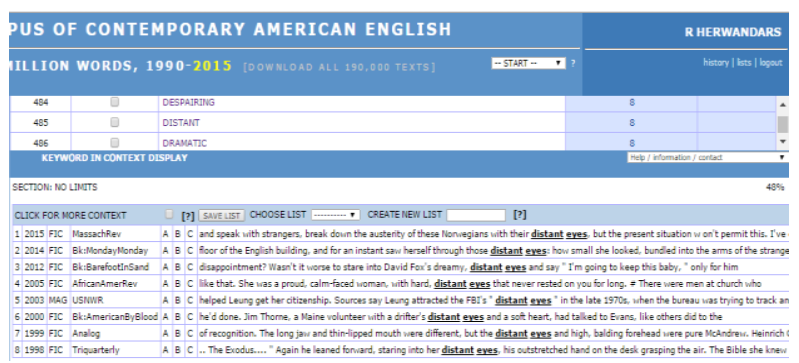

6. Data berbentuk kalimat di analisis berdasarkan norma atau eksplitasinya dan dilihat makna yang muncul dari kalimat tersebut dengan merujuk pada kamus Merriam Webster dan Oxford Advanced Learner's Dictionary (OALD) 


\section{ANALISIS DATA}

Tipe Semantis adjektiva 'PHYSICAL PROPERTY' (PROPERTI FISIK) Kolokasi Nomina ' $E y e$ ' Frekuensi 50 Tertinggi dari 500 Frekuensi

Dalam tipe semantik PROPERTI FISIK, terdaftar sejumlah 12 (dua belas) adjektiva dari 50 (lima puluh) frekuensi tertinggi. Dalam analisis akan diawali dengan adjektiva no 1 Blind eye diikuti contoh kalimat dengan nomer 26 (dua puluh enam).

\section{Blind eye (tunggal)}

Contoh kalimat:

26. You'll have a blind eye to the fact that I don't live here.

27. Syrian Army border guards willing to turn a blind eye to smuggling in exchange for...

28. Clarence wasn't one to turn a blind eye to the practices of others

29... and they turned a blind eye to the horrible things he was doing to..

30. So it was possible to turn your blind eye to what was going on to that direction

'A 'blind eye' dalam kalimat (26) tidak berarti mata buta sebagai makna lateral tetapi 'unwilling to perceive' (Webster) tidak mau menerima kenyataan bahwa temannya tidak tinggal ditempat ini. Frasa yang menonjol dari kelima kalimat ada empat yang merupakan idiom dengan arti to ignore a problem rather than to solve it'atau mengabaikan masalah daripada menyelesaikannya, dalam kalimat (27 sampai dengan 30) 'to turn a blind eye (tunggal) adalah idiom. Maknanya sesuai dengan definisi yang terdapat dalam kamus OALD yaitu 'to pretend not to notice something' atau memungkiri akan sesuatu hal dikarenakan tidak suka atau tidak ingin terlibat. Dalam kamus Webster tercatat 'turn blind eye' dengan makna yang sama dengan definisi yang ada dalam OALD. Walaupun memiliki makna konotatif, namun sudah dalam bentuk baku atau fixed. Adjektiva 'blind' sebagai anggota HUMAN PROPERTY merupakan tipe semantis periferal yang tidak memiliki unsur 'gradable' 'he is very blind'. Lebih tepatnya, 'he is totally blind'. 'Blind' bisa berfungsi sebagai nomina, atau verba di samping sebagai adjektiva.
Data 'blind eye' tercatat dari 30 (tiga puluh) hit terdiri atas: 11 (sebelas) teks percakapan, 9 (sembilan) teks fiksi, 4 (empat) teks berita dan 6 (enam) teks majalah.

\section{Sharp eye /s \\ Contoh kalimat:}

31. The headmistress would be keeping a sharp eye on the proceeding.

32. Her husband was a witty man, with a sharp eye for irony.

33. and our team's sharp eyes are peeled

34. The teacher said I had sharp eyes.

35. A hungry falcon soars high above earth. It sharp eyes scan the ground.

Makna dari `sharp eye` (eyes) adalah makna konotatif yaitu memiliki ketajaman dalam mengawasi, sigap untuk memahami sesuatu. 'Sharp' termasuk dalam kategori substansialitas (Raskin 1994) seperti dalam kalimat (31), Kepala sekolah akan mengawasi keteraturan jalannya acara dan kalimat (32), Suaminya sangat pandai atau sigap menggunakan ironi. Kedua kalimat tersebut, menggunakan 'eye' tunggal merujuk pada kemahiran tertentu saja. Sementara, pada kalimat (34) dan (35) menggunakan majemuk 'eyes' yang merujuk pada kemampuan mengerti atau menguasai hal secara umum.

Data menunjukkan bahwa majoritas teks dari 30 (tiga puluh) hits, ada 23 (dua puluh tiga) teks fiksi, 1 (satu) teks akademik, 5 (lima) teks majalah, dan 1(satu) teks berita. Frasa 'sharp eye(s)' merupakan norma sesuai dengan definisi sebagaimana dalam kamus OALD dan Webster 'quick to notice, understand things or react'

\section{Beautiful eyes \\ Contoh kalimat:}

\section{He had the most beautiful eyes}

37. She glared at me with her beautiful eyes.

38. She couldn't seem to stop her beautiful eyes from roaming over him again.

39. She has very beautiful eyes.

40. Look at those beautiful eye.

Adjektiva 'beautiful' termasuk adjektiva yang berasal dari nomina 'beauty' yang normanya mudah untuk diidentifikasi. Frasa ini memiliki makna denotatif atau makna literal tunggal yang banyak dipakai dalam percakapan dan 
termasuk kategori 'physical state' (Raskin 1994). Data ini terdiri atas 16 (enam belas) teks fiksi, 17 (tujuh belas) teks percakapan, 3 (tiga) teks majalah, 1 (satu) teks berita dan 3 (tiga) teks akademik.

\section{Pale eyes}

Contoh kalimat:

41. They were beautiful and loyal, with pale eyes and long black hair.

42. He had strange pale eyes.

43. Her pale eyes were huge.

44. Their pale eyes no longer see.

45. Each had long dark hair and pale eyes;

Adjektiva 'pale' termasuk adjektiva dasar yang mudah pula untuk mengidentifikasi normanya. Frasa ini memiliki makna denotatif atau makna literal tunggal yang masuk dalam kategori 'physical state' (Ruskin 1994). Dari data 30 (tiga puluh) hits, seluruhnya merupakan data teks fiksi.

\section{Beady eye (s) \\ Contoh kalimat:}

46. He lifted beady eyes to the secretary, 'tonight'?

47. Myrna Lee took her money, but keep her beady eyes fixed on her face.

48. Its dark, beady eyes search constantly for dangers.

49. Nora's beady eyes bulged in terror.

50. His beady eyes flared brightly, but it was only outward sign.

Adjektiva 'beady' termasuk dalam adjektiva yang berasal dari nomina 'bead', yang berarti manik-manik yang ada lubangnya, sedangkan 'beady eye' berarti mata yang seperti manik manik, bulat kecil dan bersinar dalam kalimat (46-50) 'beady eyes' sedang mengawasi segala sesuatu dengan seksama atau dengan penuh curiga. Adjektiva ini juga mudah untuk mengidentifikasi normanya. Frasa ini memiliki makna denotatif. Data ini, terdiri atas 23 (dua puluh tiga) teks fiksi, 17 (tujuh belas) teks percakapan, 3 (tiga) teks majalah, 2 (dua) teks berita, dan 1 (satu) teks akademik.

\section{Dry eye (s)}

Contoh kalimat:

51. There wasn't a dry eye in the house.
52. My sister has dry eyes and a burning sensation in her nose

53. As entire community feels the love, and inside, not a dry eye in the new house.

54. What can I do to relieve dry eyes? I have tried various drops.

55. I would take any amount of fish oil to relieve my painful dry eye syndrome.

Definisi dari kamus OALD `dry eye` (tunggal) adalah suatu idiom 'not a dry eye in the house' yang mempunyai makna (dengan canda) mereka tidak melakukan apapun sebagai balasan budi baik sebagaimana dalam kalimat (51) dan (53). Makna kedua, walaupun tidak ada di dalam kamus OALD tetapi ada dalam kamus Webster, terlihat jelas 'dry eyes` (majemuk) berarti suatu penyakit seperti dalam kalimat (52), (54) dan (55) yaitu semacam iritasi mata atau gejala iritasi mata yang mengganggu dan harus diobati dengan obat tetes mata atau semacamnya.

Data ini terdiri atas 1 (satu) teks fiksi, 4 (empat) teks percakapan, dan 25 (dua puluh lima) teks majalah. Jumlah jenis teks majalah ada dalam 'Saturday evening Post' dan 'Housekeeping' yang lebih mengungkapkan 'dry eyes' sebagai gejala penyakit mata.

\section{Watery eyes (hanya majemuk)}

Contoh kalimat:

56. 'These sprays effectively treat running nose and watery eyes 'says Randolph.

57. She looks skywards, her watery eyes sparkle under the morning sun as her mind races back

In time.

58. she pinned us with a pair of watery eyes and said,' I was leaving anyway'.

59. when I see her red, watery eyes, I lose it.

60. She stared up at him through watery eyes and appeared to be choking.

Kelima kalimat di atas mencerminkan makna denotatif dan konotatif. 'watery eyes' sebagaimana dalam kalimat (56) bermakna mata yang berair karena terkena penyakit. Namun, dalam kalimat (58) matanya berair atau berkaca-kaca karena terharu disebabkan harus pergi ke suatu tempat. Sedangkan pada kalimat (60), secara jelas diungkapkan gadis itu menatap seorang pria dengan berkaca kaca dan menangis tersedak karena sedih. Data ini terdiri 
atas 20 (dua puluh) teks fiksi, 1 (satu) teks akademik, dan 9 (sembilan) teks majalah,

\section{Open eyes}

Contoh kalimat

71. Fidel Castro took his last, shallow breath, his open eyes dreaming of life.

72. When I spoke to him and did nor blink, his open eyes gazing like a seal's toward paradise.

73. She was probably in her early tweenties.

Her open eyes were clouded like cotton.

74. Their conversation ended when uncle Jacob saw my open eyes

75. variations occur in the form of thickened lids around open eyes.

Adjektiva 'open eyes' selalu dalam bentuk majemuk dan memiliki makna denotatif mata terbuka. Kata 'open' merupakan adjektiva yang juga sebagai verba. Data ini terdiri atas 16 (enam belas) teks fiksi, 3 (tiga) teks majalah, 2 (dua) teks akademis, dan 1(satu) teks berita.

\section{Fresh eyes (jamak)}

Contoh kalimat:

76. When you come into an organization, you need fresh eyes.

77. I think it is time we have to look at Germany with fresh eyes.

78. Frank looked at the social scene through fresh eyes.

79. to fall in love is to see the beloved with fresh eyes,....

80. I was hoping that the state would actually reopen the case with fresh eyes.

Arti frasa 'fresh eye' tidak ditemukan dalam kamus OALD, 'Fresh' sebagai adjektiva di kamus OALD dan Webster berposisi sebelum nomina dengan arti 'new' atau baru. Sedangkan 'eye' selain merupakan salah satu anggota tubuh juga bermakna 'vision' atau visi. Oleh karena itu, makna 'fersh eyes' memiliki gabungan makna yaitu'visi baru, cara pandang yang baru. Kelima kalimat ini semuanya memiliki makna konotatif yang sama dan menjadi norma utama atau tunggal.

Data ini terdiri atas 10 (sepuluh) teks percakapan, 3 (tiga) teks fiksi, 2 (dua) teks akademik dan 7 (tujuh) teks majalah.
10. Clear eye (s)

Contoh kalimat:

81. I'm looking at it with clear eyes, that's all.

We have this, 'she waved her hand in".

82. So let's hear it one more time together: clear eyes, full hearts.

83. She's a fair-skinned Hispanic with clear eyes and the faint scent of the sea..

84. But all of this has to be understood with a little bit of clear eyes, that it comes from an essentially instability of character.

85. Could he traced his activities from March 5? The accused turned a clear eyes on the investigators. He knew he should have 'his counsel.

Makna 'clear' dalam kamus Webster memiliki arti denotatif dan konotatif dengan penjelasan dalam tiga arti yaitu jelas, mudah dimengerti dan jauh dari keraguan. Untuk arti 'clear' sebagai ' jauh dari keraguan', ada pada kalimat (81) artinya karena perempuan itu mendapatkan bukti ditangannya. Kalimat (82) memaknai' clear eyes' dengan cara melihat masalah dengan mata jernih tidak dan fokus atau 'clear to the mind'. Kalimat (83) memiliki arti denotatif mata dengan kualitas yang bening. Arti 'clear eyes' di kalimat (84) adalah metafora dari ' clear mind' dan penuh pengertian, terbuka pada kenyataan bahwa ada sisi kelemahan karakter yang menyebabkan hal itu terjadi. Arti 'clear eyes' dalam kalimat (85), penuduh minta penjelasan terhadap investigator mengenai kelengkapan kegiatan tertuduh di tanggal 5 Maret.

Data ini terdiri atas 13 (tiga belas) teks fiksi, 11(sebelas) teks percakapan, dan 4 (empat) teks majalah dan 2(dua) teks berita

11. Cold eye (s)

Contoh kalimat:

86. Fiegen's sad, cold eyes regarded me carefully.

87. Bo looked deep into her cold eyes framed by her blank expression.

88. Meade viewed himself with an engineer's cold eye, too dark of thought,.....

89. He still looked like a little killer and cast a cold eye on everyone who passed him.

90. The lama swept the audience with a cold eye. 
Adjektiva 'cold' artinya dingin dan bernuansa negatif. 'cold' diasosiasikan dengan 'es', sehingga dapat pula dikatakan 'cold eye' merupakan metafora. Frasa 'cold eyes' dalam kamus OALD mempunyai makna tidak ramah, seseorang yang tidak memiliki emosi seperti dalam kalimat (86) dan (87). Pada kalimat (88), (89) dan (90) menggunakan frasa 'cold eye' (tunggal) yang berbeda dengan 2 (dua) kalimat sebelumnya. Kata 'cold eye' diberi objek penderita mempunyai makna seperti memberi pandangan dingin pada semua orang sebagaimana dalam kalimat (89), dan tatapan dingin dimaksud menyapu para pendengarnya seperti dalam kalimat (90). Kalimat (88) mempunyai makna menatap dirinya dari sudut pandang seorang pakar insinyur. Data ini terdiri atas 20 (dua puluh) teks fiksi, 1(satu) teks akademik, dan 9 (sembilan) teks majalah.

\section{Empty eyes}

Contoh kalimat:

91. Mr Ford turned toward them as they approached, watchng with empty eyes.

92. Hundred of insects busied themselves in the ears and empty eye sockets

93. 'So many girls have empty eyes', I said.

94. I look out and see the wall. At its crest the empty eye of the tower stares down.

95. He looks up. In his empty eye socket, flashy tendrils shift lazily.

Kalimat (91) memiliki makna mata yang kosong, sedangkan kalimat (92) dan (95) berfokus kepada lekuk mata atau 'eye socket'. Sedangkan makna pada kalimat (94) memiliki makna kiasan atau konotatif dimana tower atau benteng diumpamakan sebagai manusia yang memiliki mata. Untuk kalimat (93), 'empty eyes' menjelaskan bagaimana banyak gadis gadis yang tidak berwawasan. Data ini terdiri atas 27 (dua puluh tujuh) teks fiksi, 2 (dua) teks majalah dan 1 (satu) teks berita.

Makna adjektiva+'eye' pada tipe semantis 'PHYISICAL PROPERTY' dengan frekuensi 50 teritnggi, kebanyakan memiliki arti (sense) lebih dari satu kecuali untuk adjektiva 'beautiful', 'pale' dan 'beady'. Makna konotatif di kelompok tipe ini hampir seluruhnya negatif kecuali makna konotatif 'fresh eyes'.
Eksploitasi Tipe Semantis Adjektiva PHYSICAL PROPERTY (PROPERTI FISIK) Frasa Nomina 'Eye' Frekuensi 50 Terendah dari 500 Frekuensi

Dalam kelompok eksploitasi terdapat sepuluh adjektiva+eye dan pada tabel berikut ini terlihat perbandingan antara kelompok norma terhadap kelompok eksploitasi.

Tabel 2. Bagan tipe semantis adjektiva PROPERTI FISIK (PHYSICAL PROPERTY) nomina eye

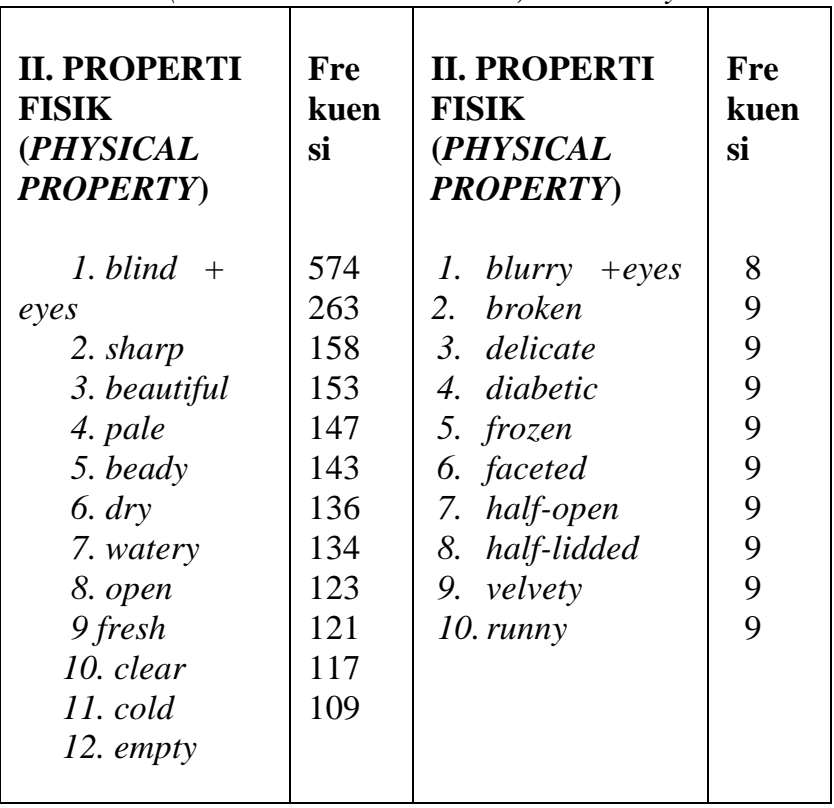

\section{Blurry eyes}

Contoh kalimat:

261. I squinted, trying to study his face through my blurry eyes. 'You are right'. 'About what? "Carma.'

262. "I said, forcing a smile at her through my blurry eyes. I had done a good job, and I knew it.

263. That blurry eyes half-asleep can see strange things.

264. When he finally awoken,staring through blurry eyes, he'd seen her image.

265. I have radioed for help." Denise looked at him with blurry eyes. "You have my son, don't you? " He seem to..

Dalam kamus Webster makna 'blurry', 'tidak fokus' atau 'seseorang yang tidak mempunyai definisi tentang sesuatu'. Makna 'blurry' pada frasa 'blurry eyes' merujuk pada makna denotatif yaitu pandangan mata yang tidak jelas, mungkin karena sedih dan khawatir seperti di kalimat (265) atau karena mata yang 
masih separuh tertidur atau belum sepenuhnya melihat seperti pada kalimat $(263,254)$.

Data ini terdiri atas 4 (empat) teks fiksi,1 (satu) teks akademis, 1 (satu) teks percakapan dan 1 (satu) teks majalah.

\section{Broken eyes.}

Contoh kalimat:

266. Her face was disoriented. She had a broken eye socket, a broken jaw.. lots of cuts across her face.

267. We'll contract the Order of the Broken

Eye where the persecution is too great, yes?

' Loard Arias bowed.

268. 'Hands on your head!' "They looked at her with wide broken eyes. There were nineteen in all, and the two who were still running-most likely

269. A big man. Beard. Overall. A broken eyes. 'Yeah?' I answered the good eye 'You 270. Sydor has a broken eye socket.

Arti broken dalam Webster adalah rusak atau patah menjadi beberapa bagian. ' broken eye' tidak lazin karena mata merupakan organ tubuh yang bagian terpentingnya adalah daging bulat yang tidak mudah bisa patah. Jika tulang yang mengelilingi mata mungkin bisa patah dalam arti terluka. Kalimat $(266,270)$ menjelaskan tulang kantong mata yang patah atau rusak 'broken eye socket'. Kalimat (267) the 'Order of the Broken Eye' dengan diawali huruf besar merujuk pada aturan the Broken Eye suatu nama organisasi. ' Broken eyes' pada kalimat (268) 'they' merupakan imigrant yang tertangkap dan sedang di interogasi. Mereka mengalami penderitaan sehingga arti 'broken eyes' diasosiasikan pada mata yang penuh kesedihan.

Adjektiva Data ini terdiri atas 6 (enam) teks fiksi, dan 1 (satu) teks akademis.

\section{Delicate eye/s}

\section{Contoh kalimat:}

271. These soft-tipped liners won't tug at delicate eye skin

272. diseases such as macular degeneration or uncontrolled glan- coma may damage

these delicate eye structure.

273. The infant's delicate eye and eye brows, were gently outlined with.

274. TAKE CARE OF YOUR EYE collagen and fat loss under delicate eye skin makes

crow's feet......
275. Around the delicate eye area, we like using a gentle mineral sunscreen.

Mata adalah organ tubuh yang sangat lembut dan rentan. Sehubungan dengan hal itu, maka contoh di atas, adjektiva 'delicate eye/s' lebih fokus kepada ' delicate eye' sebagai adjektiva terhadap nomina 'area', 'structure' dan 'skin'. Hanya ada satu kalimat (273) yang merujuk pada frasa 'delicate eye' dengan makna denotatif yaitu mata seorang bayi yang masih halus. Namun yang lebih menonjol adalah makna mengenai struktur ataupun kulit dan daerah sekitar mata yang sensitif, halus dan rentan. Data ini terdiri atas 6 (enam) teks majalah dan 1(satu) teks fiksi.

\section{Diabetic eye (tunggal)}

Contoh kalimat:

276. Diabetic eye damage is the singular largest cause of blindness before old

277. For more information on diabetic eye disease, call Prevent Blindness at 1-800-331-

$$
2020 \text { or Visit... }
$$

278 laser theraphy in the treatment id sightthreatening retinophaty, have improved the management of diabetic eye damage.

279. NEI conducts large-scale public and professional health education efforts focused on

glaucoma, diabetic eye disease, and low.

280. It raises your blood-sugar levels and blood pressure, and can make diabetic eye $\underline{\text { disease }}$

worse.

Fungsi frasa nomina ' diabetic eye' berubah fungsi menjadi frasa adjektiva terhadap nomina'damage' dan disease' Makna utama ada di nomina setelah nomina 'eye'. Frasa di kelima kalimat ini merujuk pada spesifik frasa merujuk pada English for Specific Purposes (ESP) di bidang kesehatan, kedokteran atau penyakit mata. Oleh karena itu datanya terdiri atas 4 (empat) teks akademis, dan 4 (empat) teks majalah.

\section{Frozen eye/s}

Contoh kalimat:

281. His glazed and frozen eyes stared at her, and then his mouth moved.

282. For this, I thought then, staring into the milky, frozen eyes of the dead.

283. Storm gently disarms him, and the two men are for a moment frozen eyes, the teeth, 
the coat stil thick.

284. Tears welled at the corners of his frozen eyes.

285 . His cold, frozen eyes were locked on mine.

Arti adjektiva 'frozen' ada dua. Pertama arti dari 'frozen eyes' pada kalimat (282) yakni mata yang beku dan dingin disebabkan tubuh yang sudah mati, sama dengan kalimat (283) ketika mengalami badai salju. Sedangkan, kedua, pada kalimat (281), (284) dan (285) arti 'frozen eye' menjelaskan ekspresi dingin dan tidak bersahabat. Data ini terdiri atas 7 (tujuh) teks fiksi, 1 (satu) teks percakapan

\section{Faceted eyes}

Contoh kalimat:

286. Ruth remarked, craning his neck and blinking wind blown particles out of his faceted eyes.

287. Observing the mnog, I noted their faceted eyes. Using faceted eyes, they can't have complex neural systems as...

288., her gaze still on Meguet, she saw the black prism, the faceted eyes of power, hanging in the still darkness within a triple ring of time.

289. Worldmaster Jonesput his cup of coffee down and looked deep into the many faceted deal?". eyes of the Hivekeeper. "Do we have a

290. notice of Proffessor Oates, however, each passerby stopped in mid-flight to aim

faceted eyes for a brief, wary inspection of the bundled-up intruder.

Adjektiva ' Faceted' memiliki dua arti dalam Webster. Pertama, bagian element dari suatu benda ' a part of element of something' dan kedua, permukaan kecil dan datar dari batu permata.'a small, flat surface on a jewel'. Kalimat (286) memiliki arti pertama karena bagian element terungkap dengan bagaimana angin meniup partikel dari 'faceted eyes', 'wind blown particles out of his face". Untuk kalimat (287), arti kedua lebih sepadan. Bagaimana 'mnog' yang tidak jelas mahluk apa sebenarnya itu, memiliki permukaan mata yang seperti batu permata, bening sehingga seakan tidak memiliki sistim syaraf yang kompleks. Pada kalimat (288), faceted eyes merujuk pada kekuatan atau 'power', dan pada kalimat (289) merujuk pada manusia sebagai penjaga lebah. Kalimat (290) merujuk kepada dua objek yaitu 'faceted eye' terhadap pengawasan 'inspection' dari seorang pengganggu 'intruder". Frasa adjektiva 'faceted eyes' memiliki arti yang unik karena mata dibayangkan bagaikan permukaan permata yang halus, sangat tidak lazim tapi justru menjadi terekam dalam ingatan. Keunikan ini sesuai dengan salah satu kriteria eksploitasi. Perumpamaan ekstrim ini tercermin dari data yang seluruhnya terdiri atas teks fiksi, karena teks fiksi memiliki ruang yang tak terbatas untuk berimajinasi dalam mengekspresikan kata.

\section{Half-open eye/s}

Contoh kalimat:

291. In the wavering glare, the boy's half-open eyes seemed to be alive and watching him.

292. Lucile stroked the fur of her dead BonBon, who seemed asleep with half-open eyes.

293. He turned to us with yearning, half-open eyes.

294. Through that half-open eye she watched him.

295. and white nails of the dark infant's hand, the eyelash of the half-open eye, the fine hair lying against ...

Frasa 'half-open eye/s' mempunyai arti mata yang separuh terbuka. Makna frasa ini denotatif dengan kesan malas dan negatif. Adjektiva 'half-open' berasal dari verba 'open' yang menjadi gabungan kata menjadi 'half-open'. Data ini terdiri atas 6 (enam) teks fiksi dan 1 (satu) teks akademis.

\section{Half-lidded eye/s}

Contoh Kalimat

296. Fair Haven looked the same as it always did: its windows like half-lidded eyes, its shabb doorway sagging like a...

297. He paused, gazing at me with half-lidded eyes.

298. The Cave mouth, like a half-lidded eyes, was the same, yet it seemed.

299. Muller regarded him through half-lidded eyes.

300. There was no coldness or guile in the half-lidded eyes.

Makna frasa'half-lidded' eyes tidak terdapat dalam Webster. Frasa yang ada 'heavy lidded eye' yang mempunyai arti matanya hampir tertutup. 'Half-lidded' dan 'half-open' tidak terdapat di dalam kamus OALD maupun 
Webster. Namun, hal ini dapat disimpulkan bahwa frasa tersebut dapat bermakna separuh tertutup yang didiskripsikan melalui kelopak mata yang hanya separuh. Pada kalimat (266) dan (268), subjeknya rumah dan gua diumpamakan sebagai mata yang separuh tertutup. Sedangkan kalimat lainnya, subjeknya manusia memiliki mata separuh tertutup yang bermakna denotatif. Data menunjukkan 6 (enam) teks fiksi dan 1 (satu) teks majalah.

\section{Velvety eyes}

Contoh kalimat.

301. She moved with heavy, almost sultry grace. Her dark, velvety eyes made a circuit of

the room before finally coming to rest on the couch.

302. But its velvety eye shadows are pure temptation..

303. " Hey boy!" the Dicantrop turned his great velvety eyes in their sockets.

304. down into his stepmother's beautiful face, her troubled brow, her deep velvety eyes.

Always the peacemaker. He had been in love with her since his...

305. he had the deer's poetic, velvety eyes.

Large, glistening acorns they were.

Adjektiva 'velvety' berasal dari nomina 'velvet'dengan arti bahan jenis yang agak tebal namun halus, beludru. Makna tunggal 'velvety eyes' memiliki nuansa positive. Kalimat (302) mengubah frasa nomina menjadi adjektiva terhadap nomina 'shadows' Data ini terdiri atas 6(enam) teks fiksi dan 2(dua) teks majalah.

\section{Runny eyes}

Contoh kalimat;

306. in Yong Yun village outside Sinuju, the

U.S. delegations also saw toddlers with

runny eyes and noses and a variety of skin and scalp infections.

307. Lyle turned toward her with obvious effort and she saw his runny eyes glittering.

308. She blinked her runny eyes, jerked her head up and down, and stamped on the road with..

309. A lot of people have runny noses and coughs, red and runny eyes.

310.Father Timlooks into Babs runny eyes and sees in them, blurry and reduced, himself.

Arti adjektiva 'runny' dalam Webster adalah cairan yang mengalir. ' runny eyes' bisa berarti mata yang berair seperti pada kalimat (306) karena sakit terinfeksi . Makna dari kelima kalimat sama dengan makna denotatif. Data ini terdiri atas 7 (tujuh) teks fiksi dan 1 (satu) teks percakapan.

Perbandingan kelompok tipe semantis PHYSICAL PROPERTY adjektiva+'eye' frekuensi 50 (lima puluh) tertinggi dan 50 (lima puluh) terendah dari 500 (lima ratus) frekuensi adjektiva +'eye' dapat dijelaskan sebagai berikut:

Tabel 3. Eksploitasi sintaksis Frekuensi 50 teringgi dari 500 frekuensi Frekuensi 50 terendah dari 500 frekuensi

\begin{tabular}{|l|l|}
\hline Bentuk adjektiva +eye & Bentuk adjektiva+eye \\
1. blind (nomina, verba, & 1. blurry (nomina-blur+ry) \\
adjektiva) & 2. broken (verba-broken) \\
2. sharp (nomina, adjektiva) & 3. delicate (adjektiva) \\
3. beautiful (adjektiva -beauty- & 4. diabetic (nomina,adjektiva) \\
full) & 5. frozen (verba frozen) \\
4. pale (nomina,adjektiva) & 6. faceted (verba faceted) \\
5. beady (nomina-bead-y) & 7. half-open (verba open) \\
6. dry (nomina,verba, adjektiva) & 8. half-lidded (verba lid) \\
7. watery (nomina-water-y) & 9. velvety (nomina velvet $+y)$ \\
8. open (verba, adjektiva) & 10. runny (verba run+ny) \\
9fresh (adjektiva) & \\
10. clear (verba, adjektiva) & \\
11. cold (adjektiva) & \\
12. empty (verba, adjektiva) & \\
\hline
\end{tabular}




\begin{tabular}{|c|c|}
\hline $\begin{array}{l}\text { Pembentukan adjektiva bervariasi } \\
\text { menjadi: } \\
\text { - } \quad \text { adjektiva dasar (9) } \\
\text { - } \quad \text { adjektiva berasal dari } \\
\text { nomina(30, verba } \\
\text { - } \quad \text { gabungan/compound } \\
\text { (satu kata)(1) } \\
\text { - derivasi/suffixes }\end{array}$ & $\begin{array}{l}\text { Pembentukan adjektiva bervariasi } \\
\text { menjadi: } \\
\text { - adjektiva dasar (1) } \\
\text { - adjektiva berasal dari } \\
\text { - } \text { nomina(3),verba(6) } \\
\text { gabungan/'hyphernated } \\
\text { - compound'(2) } \\
\text { - derivasi/suffixes }\end{array}$ \\
\hline Struktur frasa & Struktur frasa \\
\hline $\begin{array}{l}\text { 1. a. a blind eye- } \\
\text { b. turn a blind eye (idiom) }\end{array}$ & 1. a. blurry eyes \\
\hline $\begin{array}{l}\text { 2. a. a sharp eye/sharp eyes } \\
\text { b. keep a sharp eye on }\end{array}$ & $\begin{array}{l}\text { 2. a. broken eyes } \\
\text { b. broken eye socket }\end{array}$ \\
\hline $\begin{array}{l}\text { (idiom) } \\
\text { 3. a. beautiful eyes }\end{array}$ & $\begin{array}{l}\text { 3. a. delicate eye } \\
\text { b. delicate eye skin } \\
\text { c. delicate eye structure } \\
\text { d. delicate eye area (assosiatif) }\end{array}$ \\
\hline 4. a. pale eyes & \\
\hline 5. a. beady eyes & $\begin{array}{l}\text { 4. a. diabetic eye damage } \\
\text { b. diabetic eye disease }\end{array}$ \\
\hline $\begin{array}{l}\text { 6. a. a dry eye (idiom) } \\
\text { b. dry eyes (illnesses) }\end{array}$ & 5. a. frozen eyes \\
\hline c. dry eye syndrome & $\begin{array}{l}\text { 6. a. faceted eyes } \\
\text { b. faceted eyes of power }\end{array}$ \\
\hline 7. a. watery eyes & $\begin{array}{l}\text { c. faceted eyes of the Hivekeeper } \\
\text { d. faceted eyes for inspection }\end{array}$ \\
\hline 8. a. open eyes & (partitif) \\
\hline $\begin{array}{l}\text { 9. a. fresh eyes (konotatif) } \\
\text { b. seeing with fresh eyes } \\
\text { (idiom) }\end{array}$ & $\begin{array}{l}\text { 7.a. half-open eye/eyes } \\
\text { 8. a. half-lidded eyes }\end{array}$ \\
\hline 10. a. clear eyes (konotatif) & $\begin{array}{l}\text { 9. a. velvety eyes } \\
\text { b. velvety eye shadows }\end{array}$ \\
\hline 11. a. cold eye/eyes (konotatif) & 10. a runny eyes \\
\hline $\begin{array}{l}\text { 12. a. empty eyes } \\
\text { b. empty eye socket } \\
\text { c. empty eye of the tower } \\
\text { Struktur frasa: } \\
\text { - 'eye' menjadi unsur pusat } \\
\text { 'head word' } \\
\text { - Idiom }\end{array}$ & $\begin{array}{l}\text { Struktur frasa } \\
\text { - 'eye skin', 'eye structure', 'eye } \\
\text { area'menjadi unsur pusat atau } \\
\text { headword } \\
\text { - 'eye of power', eye of the } \\
\text { Hivekeeper', 'eye for inspection' }\end{array}$ \\
\hline
\end{tabular}




\begin{tabular}{|l|l|}
\hline $\begin{array}{l}\text { Jenis makna } \\
\text { Adjektiva dasar } \\
\text { Denotatif, konotatif. idiomatis }\end{array}$ & Jenis makna \\
adjektiva tidak lazim dan spesifik \\
& $\begin{array}{l}\text { Makna berkembang sesuai perubahan } \\
\text { posisi 'head word' atau kata utama } \\
\text { struktur frasa. Pada frasa adjektiva+ 'eye' } \\
\text { berubah menjadi kata utama non 'eye'. }\end{array}$ \\
\hline
\end{tabular}

a) Pada frekuensi 50 (lima puluh) tertinggi, ditemukan kebanyakan adjektiva dasar (cold, empty, dry, fresh, pale sharp, clear ), 2 (dua) berasal dari nomina ( beauty dan water), dan 2 (dua) dari verb, (open, blind). Jumlah adjektiva di kelompok ini merujuk kepada adjektivanya dasar yang dibuktikan ada dalam kamus Webster dan OALD. Dengan demikian fasa adjektiva+'eye' tersebut merupakan norma. Sementara Adjektiva pada frekuensi 50 (lima puluh) terendah dari 500 (lima ratus) frekuensi, memiliki adjektiva yang berasal dari verba' brake/broken', 'freeze/frozen', 'open/ half open', 'lid/ half lidded', 'run/runny'). Sebagian adjektiva ada pula yang berasal dari nomina seperti ('blur/ry,' 'diabetic', dan 'velvet/ velvety') dan 1 (satu) merupakan adjektiva dasar seperti 'delicate'. Perbedaan lainnya di kelompok frekuensi terendah ditemukan gabungan kata jenis 'hyphernated'

b) Perbedaan pada struktur frasa di frekuensi 50 tertinggi terlihat bahwa 'head word' atau unsur pusat frasa nomina' eye' tetap dominan kecuali pada 'dry eye syndrom'. Di kelompok ini juga ditemukan idioms yang cukup signifikan. Ini menandakan bahwa idiom lahir dari adjektiva dasar dan telah disepakati dan karena mudah diingat oleh pemakainya. Sementara struktur frasa di frekuensi 50 terendah dari 500 frekuensi yang menonjol adalah posisi 'headword' yang bergeser atau berubah. 'eye'(nomina) sebagai unsur pusat berubah menjadi 'skin', 'structure' dan 'area' (asosiatif) dan juga hadirnya preposisi 'of power', 'of the Hivekeeper', dan 'for inspection' (partitif). 'Diabetic eye disease' dan 'diabetic eye damage'
Menjadi frasa yang merujuk pada peruntukkan 'English for Specific Purposes' yang terekam di COCA.

c) Pada adjektiva di frekuensi 50 tertinggi+'eye" memilki makna denotatif, konotatif dan makna dari idiom yang tercermin dari majoritas ajeketiva dasar. Sementara dikelompok frekuensi 50 terendah, makna idiom tidak signifikan dibandingkan pengembangan makna akibat perubahan unsur pusat 'eye' sebagai nomina menjadi adjektiva terhadap nomina lainnya.

Dilihat dari jumlah adjektivanya, tipe semantis PROPERTI FISIK 50 frekuensi tertinggi cenderung lebih dominan daripada 50 frekuensi terendah dari 500 frekuensi, walau tidak signifikan. Dapat disimpulkan bahwa penjabaran adjektiva bernuansa kata hati atau perasaan manusia muda yang ada di 50 frekuensi tertinggi lebih dinamis baik emosi positif maupun negatif daripada yang tercermin pada sosok perasaan dewasa di kelompok 50 frekuensi terendah. Sementara yang signifikan dari sosok manusia berusia lanjut di 50 frekuensi terendah adalah sosok yang emosinya terkendali, berpengalaman dan akrab dengan penyakit tua.

\section{KESIMPULAN}

Coca menyediakan data yang sangat bernilai dalam mengembangkan berbagai penelitian di bidang linguistik. COCA menjadi sangat penting karena data yang disajikan sangat bernilai baik dilihat dari jumlah dan dilihat dari perkembangan aspek kehidupan manusia yang tercermin dalam bahasa. Bahasa mencerminkan bangsa terlihat dalam kedinamikaan sumber data di COCA yang terus menerus berubah sesuai berjalannya waktu. Beberapa tahun kedepan, akan bermunculan eksploitasi kata ataupun frasa baru yang mencerminkan 
perubahan fokus masyarakat di segala aspek kehidupan.

Saran yang dapat disumbangkan antara lain adalah pertama, dalam pengajaran bahasa, pengajar harus memanfaatkan linguistik korpus untuk dipelajari bersama para siswa karena linguistik korpus dapat membuka wawasan pembelajaran bahasa yang tidak terbatas. Pembelajar tidak lagi hanya terfokus belajardari buku gramatika dan kamus saja, tetapidapat memanfaatkan sumber data dari linguistik korpus yang tersedia yang akan menjadikan pembelajaran bahasa secara utuh dan tak terbatas.

\section{DAFTAR PUSTAKA}

[1] Atkins,B.T., M.Rundell (2008).The Oxford Guide to Practical Lexicography. Oxfors University Press.

[2] Cruse, D. 2000. Meaning in Language An Introduction to Semantics \& Pragmatics. Oxford University Press.

[3] Cresswell, J. (2009). Research Design Qualitative, Quantitative \& Mixed Methods Approaches. University of Nebraska Lincoln, SAGE Publication. Inc.
[4] Dixon,R.M.W. (1991). A Semantic Approach to English Grammr. Oxford University Press.

[5] Hanks, P. (2013). Lexical Analysis Norms and Exploitations. The MIT Press Cambridge Massachussetts, London England.

[6] Levin, M. Lindquists, (2007). Sticking One's Nose in the Data: Evaluation in Phraseological Sequence with Nose in ICAME Journal volume 31.

[7] Lindquist, Hans (2009) Corpus Linguistics and the discription of English. Edinberg university Press.

[8] McEnery,T. Hardie. A. (2012) Corpus Linguistics: Method, Theory and Practice. Ca,bridge University Press.

[9] Sinclair,J.M.(1991) Corpus, Concordance, Collocations. Oxford University Press.

[10] Sinclaie, J.M. (2004) Trust the text:language Corpus and discourse. London, Routledge

[11] Corpus of Contemporary American English (COCA) Corpus.byu.edu/coca

[12] http://www.merriem-webster.com 